\title{
Vidno radno pamćenje
}

\author{
Ivan Tomić \\ Odsjek za psihologiju, Filozofski fakultet Sveučilišta u Zagrebu, Hrvatska
}

\section{Sažetak}

Vidno radno pamćenje (VRP) skupni je naziv za procese kratkotrajnog zadržavanja vidnih informacija s ciljem trenutnog obavljanja zadatka. Posljednjih su desetak godina istraživanja u području rezultirala brojnim revolucionarnim, kako bihevioralnim, tako i neurološkim, nalazima koji su znatno promijenili načine na koje danas promatramo VRP. Ovim su pregledom obuhvaćene neke najvažnije teorijske ideje i nalazi koji su definirali istraživačke smjerove unutar područja. Rad započinjemo kratkim smještanjem VRP-a u kontekst srodnih kognitivnih procesa. Nakon prikaza najčešćih zadataka korištenih u istraživanjima VRP-a, središnji je dio rada posvećen prikazu dviju dominantnih teorija VRP-a i njihovoj usporedbi - modelima utora i modelima resursa. Nakon gotovo četrdeset godina empirijske podrške modelima utora, brojna istraživanja, objedinjena modelima resursa, revidiraju naša znanja o VRP-a. Kako bismo zaključili pitanje arhitekture reprezentacija VRP-a, dan je pregled istraživanja koja su pokušala odgovoriti na pitanje jesu li reprezentacije VRP-a sastavljene od pojedinačnih vidnih svojstava ili već integriranih objekata. Kako ni jedan od pristupa ne može u potpunosti objasniti rezultate istraživanja, najizgledniji se odgovor na pitanje o jedinicama kodiranja nalazi u hijerarhijskim modelima koji pretpostavljaju kako vidne informacije kodiramo i na razini svojstava, ali i na razini integriranih objekata. U drugom su dijelu rada opisane tri bitne komponente funkcioniranja VRP-a: usvajanje, dosjećanje i zaboravljanje informacija. Područja istraživanja ovih komponenata obilježena su provjerama relativno suprotstavljenih modela te metodološkim novinama uvedenima kako bi se na što obuhvatniji način ispitale postojeće hipoteze.

Ključne riječi: vidno radno pamćenje (VRP), modeli resursa, modeli utora, zapamćivanje, retencija, zaboravljanje

\section{Što je vidno radno pamćenje (VRP)?}

Vidno pamćenje definiramo kao zadržavanje i obradu vidnih informacija kada one više nisu dostupne u osjetnom sustavu (Campana, 2010). Kao i s drugim sustavima pamćenja, taksonomija vidnog pamćenja ima tri razine: osjetno, kratkoročno ili radno i dugoročno vidno pamćenje. Povijesni je prekursor VRP-a kratkoročno pamćenje (Atkinson i Shiffrin, 1968), pri čemu je pridjevom "radno" stavljen naglasak na aktivnu obradu i upravljanje, a ne samo na pasivnu kratkoročnu

Ivan Tomić, Odsjek za psihologiju, Filozofski fakultet u Zagrebu, Ivana Lučića 3, 10000 Zagreb, Hrvatska. E-pošta: itomic3@ffzg.hr 
pohranu vidnih informacija. Najkraće rečeno, VRP se definira kao kratkoročno aktivno zadržavanje vidnih informacija s ciljem obavljanja trenutnog zadatka (Luck i Vogel, 2013).

Polazeći od pretpostavke o različitim spremnicima pamćenja, VRP se često prikazuje kao skup procesa koji spajaju osjetno i dugoročno pamćenje te obrađuju informacije pohranjene u njima. Interakcija ikoničkog pamćenja i VRP-a omogućuje opstanak vidnih reprezentacija i nakon što nestane osjetno podraživanje koje je omogućilo njezin nastanak. Cjelokupno vidno iskustvo moguće je razložiti na niz kratkotrajnih reprezentacija pohranjenih u ikoničkom pamćenju a čije je trajanje određeno pokretima očiju (sakadama) i pauzama između tih pokreta (fiksacijama). Irwin (1991) je pretpostavio kako mora postojati neka vrsta kognitivnog mehanizma koja omogućuje integraciju kratkotrajnih ikoničkih u dugotrajniju reprezentaciju potrebnu za funkcionalnu interakciju s okolinom. U nizu eksperimenata pokazao je kako reprezentacije ikoničkog pamćenja ne mogu preživjeti sakade, ali da mehanizam vrlo sličan ili možda čak identičan VRP-u omogućuje njihovo povezivanje u trajniju reprezentaciju. Jednostavnije rečeno, VRP omogućava povezivanje pojedinih vidnih scena u kontinuiranu projekciju koju doživljavamo kao vid. Dodatno, istraživanja su pokazala kako pamćenje sadržaja u VRP-u počiva na aktivnosti vidnih osjetnih područja (Emrich, Riggall, LaRocque i Postle, 2013; Harrison i Tong, 2009; Jonides, Lacey i Nee, 2005; Postle, 2006, 2015; Zokaei, Manohar, Husain i Feredoes, 2014), ali i da se aktivnost nekih neuralnih korelata VRP-a ne razlikuje neovisno o tome jesu li vidni podražaji koji se pamte prisutni u osjetu vida ili ne (Tsubomi, Fukuda, Watanabe i Vogel, 2013). Sve je veći broj sličnih istraživanja koja naglašavaju isprepletenost procesa VRP-a, vidne percepcije i osjetnog pamćenja (Fallon, Zokaei i Husain, 2016).

Odnos radnoga pamćenja (RP) i dugoročnog pamćenja (DP) također je temeljito istraživan. U Baddeleyevom (2007) su modelu RP i DP sustavi koji, iako u gotovo neprekidnoj interakciji, predstavljaju jasno odvojene spremnike pamćenja namijenjene pohrani bitno različitih reprezentacija. Za razliku od Baddeleya, Cowan (2001) pretpostavlja kako se u RP-u i DP-u nalaze iste reprezentacije, te da je jedina razlika među njima u stupnju aktiviranosti, odnosno kapacitetu pažnje koja im je pridana. Samim time je podjela pamćenja na RP i DP, barem u smislu multikomponentnih modela, preuveličana. Neupitno, istraživači ne mogu opisati cjelokupno funkcioniranje RP-a bez referiranja na njegovu interakciju s DP-om. Područje istraživanja odnosa VRP-a i VDP-a posljednjih je godina posebno aktivno, pri čemu su nalazi neuroloških istraživanja naročito korisni u rasvjetljavanju odnosa ovih sustava (Lewis-Peacock, Drysdale, Oberauer i Postle, 2012).

VRP se često dovodi u vezu i s procesima pažnje pri čemu istraživači najčešće pokušavaju otkriti jesu li procesi pažnje nužni i/ili dovoljni za ulazak sadržaja u VRP. Neke od teorija RP-a (npr. Cowan, 2001; Oberauer, 2002) pretpostavljaju kako se RP odnosi na procese obrade sadržaja koji se nalaze u fokusu pažnje. Na taj način ovi autori gotovo izjednačuju RP i procese pažnje. Većina nalaza istraživanja ide u 
prilog pretpostavci kako RP i pažnja, unatoč brojnim sličnostima koje su pokazala kako bihevioralna, tako i neurološka istraživanja, nisu različiti nazivi istih mehanizama. Štoviše, istraživanja upućuju na to da su različiti oblici pažnje ključni za efikasno funkcioniranje VRP-a u određenim fazama obrade. Na primjer, izvršni procesi pažnje nužni su prilikom kodiranja i obrade sadržaja iz RP-a, dok se pasivno zadržavanje sadržaja odvija neovisno od dostupnih resursa pažnje (za detaljan pregled vidi Fougnie, 2008). Ukratko, istraživanja pokazuju kako je VRP skup složenih procesa koji su u stalnoj interakciji s drugim kognitivnim procesima poput osjeta i percepcije, osjetnog i dugoročnog pamćenja te pažnje. Pritom, istraživači se razlikuju s obzirom na stupanj u kojem izjednačavaju VRP s procesima s kojima je ono u stalnoj interakciji.

\section{Zadaci u istraživanjima VRP-a}

Metodologija korištena $u$ istraživanjima VRP-a raznolika je. To podjednako vrijedi i za podražajni materijal koji se koristi, ali i za vrstu zadataka kojom se ispituju procesi VRP-a. Kao podražajni materijal koriste se prikazi boja (Wilken i Ma, 2004), jednostavni ili složeni geometrijski likovi (Zhang i Luck, 2008), znakovi nepoznatog pisma (Hartley, Speer, Jonides, Reuter-Lorenz i Smith, 2001), različito orijentirani objekti (Jiang, Shim i Makovski, 2008), prostorna gustoća (Magnussen, Greenlee i Thomas, 1996), obrasci u matrici (Della Sala, Gray, Baddeley, Allamano i Wilson, 1999), lica (Jiang i sur., 2008) itd. Iako postoji niz zadataka u kojima se ovi materijali mogu koristiti, ovdje su ukratko opisane dvije široke kategorije zadataka - zadatak detekcije promjene i zadatak procjene svojstva na kontinuiranoj skali. Dva su razloga zašto ćemo se usmjeriti samo na ove dvije skupine zadataka. Prvo, ove kategorije pokrivaju najčešće korištene vrste zadataka u istraživanjima VRP. Drugo, svaka od njih povijesno prati te odražava po jedan značajan teorijski pravac i pretpostavke vezane uz prirodu VRP. Zadatak detekcije promjene korišten je u okviru istraživanja teorija utora (engl. Slot models; Luck i Vogel, 1997), dok je zadatak procjena svojstva na kontinuiranoj skali poslužio teorijama resursa (Bays i Husain, 2008) za dokazivanje njihovih pretpostavki o radu VRP-a. Dvije su vrste zadataka ovdje opisane kao uvod u pregled dvije dominantne teorije VRP-a.

Zadatak detekcije promjene (Pashler, 1988; Phillips, 1974) klasična je paradigma ispitivanja VRP-a u kojoj se od sudionika traži da procjeni jesu li dva uzastopna prikaza ista (Slika 1.a.). U klasičnoj se verziji ovog zadatka (Luck i Vogel, 1997) sudionicima prvo prikazuje vidni podražaj koji trebaju zapamtiti. Elementi u takvom prikazu mogu biti iz kategorije bilo kojih od ranije navedenih podražaja. Nakon kratkog prikazivanja (obično $<1$ sekunde) niza za pamćenje sudionicima se prikazuje prazan ekran čijim se trajanjem određuje vrijeme zadržavanja informacija u VRP-u. Naposljetku, sudionicima se prikazuje ekran koji je ili identičan onom u fazi učenja ili je po barem jednom elementu različit od prikaza koji se pamtio. Zadatak je sudionika odgovoriti razlikuju li se dva prikazana ekrana, a zavisna je varijabla točnost detekcije promjene na kojoj se uradak opisuje binarnim ishodom. 
Iako niz godina dominantna istraživačka paradigma, novija istraživanja upućuju ovom zadatku ozbiljan prigovor. Naime, učinak u ovom zadatku malo govori o tome koliko je detaljno svaki prikazani objekt zapamćen. Uspješna detekcija promjene ne odražava potpuno precizno pamćenje cijelog prikaza jednako kao što propust detekcije ne znači da ni jedna informacija iz prikaza nije bila pohranjena (Pertzov, Bays, Joseph i Husain, 2013). Točna detekcija govori nam samo da je prikaz zapamćen dovoljno dobro da bi ga se moglo razlikovati od prikaza s objektima kategorički različite kvalitete.

Zadatak procjene svojstva na kontinuiranoj skali (Wilken i Ma, 2004) relativno je nova paradigma u istraživanju VRP-a (Slika 1.b.), a predložena je upravo kao reakcija na prigovore zadatku detekcije promjene. $U$ oba se zadatka sudionicima prvo prezentira niz objekata (npr. kvadrati različitih boja) koje moraju upamtiti. Nakon intervala retencije na novom ekranu prikazuje se lokacija kvadrata čiju boju prikazanu u prvom nizu moraju reproducirati. U zadatku pamćenja boja sudionici svoje odgovore daju odabirom boje na krugu na kojem se nalazi cijeli spektar boja. Sudionici odabiru poziciju na krugu na kojoj se nalazi boja za koju vjeruju da je njome bio obojan podražaj koji su trebali zapamtiti. Uradak u takvom zadatku predstavlja preciznost pamćenja, operacionaliziran kao razlika između vrijednosti svojstva koje su sudionici morali reproducirati i vrijednosti koja je reproducirana (razlika odgovora i podražaja). Manji rezultat upućuje na veću preciznost dosjećanja, a distribucija tih pogrešaka dosjećanja predmet je daljnjih obrada. Dominantan pristup analiziranju distribucije zabilježenih pogrešaka dosjećanja jest testiranje modela mješovitih distribucija (engl. Mixture models; McLachlan i Peel, 2000). Modeli mješovitih distribucija polaze od pretpostavke kako je opažena distribucija pogrešaka zapravo skup dvije ili više distribucija koje nemaju jasnu razliku, odnosno kako ne postoji manifesna varijabla na temelju koje bismo mogli razvrstati rezultate u pripadajuće skupine odgovora. Na opaženoj distribuciji testira se hipoteza o vjerojatnosti postojanja barem dviju preklopljenih distribucije ${ }^{1}$ : npr. one koja odražava pamćenje objekta (normalna distribucija oko vrijednosti podražaja koje je trebalo reproducirati) i one koja je odraz pogađanja (uniformna distribucija) (Zhang i Luck, 2008).

\footnotetext{
${ }^{1}$ Model mješovitih distribucija je probabilistički model - statističkom se metodom procjenjuje vjerojatnost postojanja pojedinih komponenata rezultata. Na primjer, u nizu za pamćenje mogli su biti prikazani kvadrati zelene, plave i crvene boje te se kasnije od sudionika traži da reproducira boju kvadrata s položaja na kojem se nalazila crvena boja. Svaki odgovor blizu crvene boje povećava proporciju odgovora koji pripadaju normalnoj komponenti distribucije centriranoj oko vrijednosti traženog elementa (vjerojatnost pamćenja). Što je odgovor udaljeniji od tražene boje, u većoj mjeri pridonosi proporciji odgovora koji spadaju u komponentu pogađanja.
} 
Slika 1. Shematski prikaz zadatka detekcije promjene i procjene svojstva na kontinuiranoj skali

a) Zadatak detekcije promjene

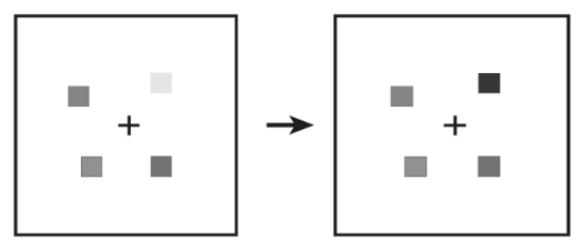

b) Procjena svojstva na kontinuiranoj skali

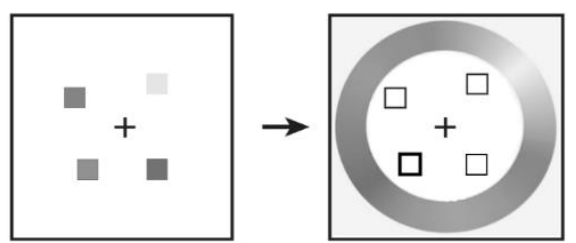

\section{Priroda reprezentacija VRP-a}

Gotovo svi istraživači pamćenja, neovisno o konceptualizaciji od koje kreću i komponenti pamćenja koju proučavaju, pokušavaju odgovoriti na temeljno pitanje o ljudskom pamćenju - koliko možemo zapamtiti. Pitanje kapaciteta VRP-a staro je koliko i sama ideja o njemu. Tradicionalno, i još uvijek prevladavajuće stajalište o kapacitetu VRP-a je ono o ograničenoj, manjoj količini informacija koju možemo pohraniti, poput Millerova (1956) magičnog broja 7 ili Cowanova $(2001,2005)$ broja 4. Brojna su istraživanja došla do sličnih zaključaka o gornjoj granici kapaciteta RPa (Luck i Vogel, 1997; Vogel, Woodman i Luck, 2001). Ideja o ograničenim reprezentacijskim kapacitetima VRP-a koji se mogu opisati točnim brojem informacija koje osoba može zadržati objedinjeni su pod nazivom modeli utora VRP-a. Teorije koje spadaju pod pristup modela utora dijele zajedničku pretpostavku o načinu pohrane informacija u VRP-u: ako je kapacitet VRP-a $\left(K_{\max }\right)$ veći od količine senzornih informacija koje treba pohraniti, tada će sve informacije biti pohranjene; ako je količina senzornih informacija veća od $K_{\max }$, tada će količina zapamćenih informacija biti jednaka $K_{\max }$, dok preostale informacije neće biti pohranjene. Pamćenje bi se prema modelima utora moglo opisati i kao "sve ili ništa": informacije su ili zapamćene u cijelosti, ili nisu zapamćene uopće. Važno je napomenuti kako novije verzije modela utora dozvoljavaju varijabilnu preciznost reprezentacija, a samim time i procjena $K_{\max }$ između različitih podražajnih nizova (Luck i Vogel, 2013; Zhang i Luck, 2008). Ova pretpostavka nije dio tradicionalnih modela utora (Luck i Vogel, 1997), već je predložena kao odgovor kritikama alternativinih modela VRP-a.

Drugu skupinu modela o kapacitetu VRP-a čine modeli resursa koji funkcioniranje VRP-a ne promatraju u terminima gornjih granica broja zapamćenih objekata, već u terminima preciznosti kojima su ti objekti zapamćeni (Ma, Husain i Bays, 2014). Iako modeli utora i modeli resursa dijele zajedničku pretpostavku o ograničenosti kapaciteta VRP-a, potonji se ne slažu s pretpostavkom o postojanju ograničenog broja informacija (elemenata) koju VRP može pohraniti. Štoviše, modeli resursa tvrde kako kapacitet VRP-a možemo bolje opisati kao ograničenu količinu fleksibilno djeljivih resursa koji nisu operacionalizirani brojem objekata 
(Bays i Husain, 2008; Fougnie, Suchow i Alvarez, 2012; Wilken i Ma, 2004). Modeli resursa počivaju na dvije temeljne pretpostavke (Ma i sur., 2014). Prva se odnosi na postojanje reprezentacijskog šuma, tj. slučajnih fluktuacija u reprezentaciji podražaja u VRP-u. To znači da model resursa dozvoljava variranje u preciznosti upamćenog čak i kada je broj upamćenih objekata manji od $K_{\max }$ kojeg pretpostavljaju tradicionalni modeli. Druga pretpostavka govori kako količina reprezentacijskog šuma raste s porastom broja podražaja koji se pamte. Uzevši ih zajedno, ove dvije pretpostavke temeljne su za usporedbu modela utora i modela resursa.

\section{Dokazi u prilog modela utora}

Rad Lucka i Vogela (1997) predstavlja klasičnu studiju u području istraživanja kapaciteta VRP-a. U tom eksperimentu, provedenom pod paradigmom detekcije promjena, rezultati su pokazali kako sudionici s lakoćom mogu detektirati promjene kada su prezentirani nizovi sastavljeni od 3 ili 4 objekta, ali i da taj učinak opada kada su nizovi duži. Na temelju tih su rezultata Luck i Vogel zaključili kako je kapacitet VRP-a ograničen određenim brojem $(3-4)$ objekata koje sudionici mogu upamtiti. Nakon njih i druga su istraživanja došla do istog zaključka o kapacitetu VRP-u (Cowan, 2005; Rouder i sur., 2008).

Osim pretpostavke o broju elemenata koje sudionici pamte, modeli utora imaju i snažne pretpostavke vezane uz preciznost kojom sudionici pamte elemente. Neovisno o veličini zapamćenog niza, sudionici ili pamte sve informacije ili ne pamte ni jednu informaciju o objektu iz niza. Štoviše, originalni modeli utora pretpostavljaju kako je reprezentacijski šum za zapamćene objekte neznatan (Luck i Vogel, 1997; Pashler, 1988) te da bi preciznost trebala biti maksimalna kad god je objekt zapamćen. Zhang i Luck (2008) su eksperimentalno provjeravali hipotezu o varijabilnoj preciznosti VRP-a. U provedenom su eksperimentu u kojem su se koristili nizovima od 1, 2, 3 i 6 elemenata pronašli su kako se preciznost smanjivala za prikaze do tri elementa, no nakon toga ostala stabilna. Kako bi objasnili rezultate eksperimenta, predložili su modifikaciju originalnog modela utora, koji nazivaju utori + uprosječivanje (engl. slots + averaging). Kada je broj dostupnih utora veći od broja elemenata koje treba upamtiti, kapacitet tih neiskorištenih utora ravnomjerno će se rasporediti na sve podražaje iz niza što će dovesti do porasta preciznosti pamćenja. Na primjer, ako je zadatak zapamtiti dva elementa, tada će svaki element dobiti jedan utor, ali i polovicu trećeg utora koji je ostao neiskorišten. $\mathrm{Na}$ temelju ovih rezultata i proširivanje teorijskih pretpostavki, autori su zaključili kako podaci ne idu u prilog temeljnoj pretpostavci modela resursa, već da su potvrđene pretpostavke modela utora. 


\section{Dokazi u prilog modelima resursa}

Dok je pretpostavka o preciznosti pamćenja unutar modela utora uvedena kako bi se objasnila opažena variranja u preciznosti s porastom upamćenog niza, temeljna je pretpostavka modela resursa upravo ona vezana uz odnos količine i preciznosti upamćenog, tj. kvantitete i kvalitete upamćenog. Modeli resursa Baysa i Husaina (2008) i van den Berga, Shina, Choua, Georgea i Maa (2012) pretpostavljaju potencijski odnos između odnosa količine upamćenog i preciznosti kojom je svaki objekt zapamćen. Niz je studija potvrdio očekivani odnos dužine upamćenog niza i preciznosti kojima su objekti niza upamćeni (Bays, Catalao i Husain, 2009; Bays, Gorgoraptis, Wee, Marshall i Husain, 2011; Bays i Husain, 2008; Mazyar, van den Berg i Ma, 2012; Palmer, 1990; van den Berg i sur., 2012). Druga istraživanja nisu testirala potencijski odnos, no također su pronašla porast $u$ varijanci pogrešaka procjene svojstava s porastom dužine pamćenih nizova (Gorgoraptis, Catalao, Bays i Husain, 2011; Wilken i Ma, 2004).

Schneegans i Bays (2016) uspoređivali su modele utora i modele resursa analizirajući preciznost, pogrešna dosjećanja (zamjena traženog elementa i nekoga drugoga prisutnog u prikazu za pamćenje) te vrijeme dosjećanja. Eksperimentalni se zadatak u tom istraživanju sastojao od pamćenja lokacija elemenata ( $1-8$ elemenata) različitih boja (glavno istraživanje) i oblika (replikacijska studija). Prema modelima utora, porast broja elemenata nakon popunjavanja svih dostupnih utora (između 2 i 3; Zhang i Luck, 2008) mijenja samo broj elemenata izvan pamćenja, no ti elementi ni na koji način ne utječu na uradak u zadatku, neovisno o tome za koliko broj elemenata u prikazu premašuje broj utora. Rezultati su pokazali kako se preciznost dosjećanja smanjuje, dok pogrešna dosjećanja te vrijeme dosjećanja jednolično rastu i nakon što broj elemenata u nizu premaši broj pretpostavljenih utora kojima osoba raspolaže. Drugim riječima, elementi koji bi prema modelima utora trebali ostati van pamćenja smanjivali su preciznost dosjećanja, povećavali vjerojatnost zamjene traženog elementa za neki drugi prikazani element te produljivali vrijeme dosjećanja.

U pokušaju da daju konačan odgovor na pitanje o strukturi reprezentacija VRP-a van den Berg, Awh i Ma (2014) testirali su pristajanje empirijskih podataka većem broju modela dobivenih kombiniranjem različith hipoteza o najbitnijim istraživačkim problemima vezanima uz rad VRP-a. Usporedbom svih značajnih teorija autori su istaknuli dimenzije kojima je moguće opisati postojeće konceptualizacije VRP-a, a one se odnose na pretpostavke: 1) o preciznosti reprezentacija u VRP, 2) o broju zapamćenih objekata i 3) o pogreškama dosjećanja prostorno bliskih objekata. Vodeći se tim dimenzijama, tradicionalni modeli utora poput onih koje su predložili Luck i Vogel (1997) i Pashler (1988) pretpostavljaju kako su i preciznost pamćenja i broj upamćenih objekata fiksni. Fougnie i suradnici (2012) i van den Berg i suradnici (2014) pak pretpostavljaju kako sudionici pamte sve prikazane objekte (neke vrlo površno) te da preciznost tih reprezentacija varira od podražaja do podražaja tijekom eksperimenta. Kombinacijom ovih triju dimenzija 
autori su generirali veći broj modela te podacima testirali pristajanje svaki od njih. Na temelju usporedbe simuliranih modela i agregiranih rezultata deset provedenih i objavljenih istraživanja unazad deset godina autori su pronašli kako podaci najbolje pristaju modelima izvedenima na temelju pretpostavki modela resursa. Podaci su upućivali na to da je preciznost reprezentacija varijabilna čak i kod malog broja zapamćenih elemenata, kako ne postoji gornja granica broja zapamćenih elemenata, te da nezanemariv dio pogrešaka pamćenja odražava dosjećanje elemenata koji su bili prikazani zajedno s traženim elementom. Ovi su nalazi vrijedili i za rezultate prikupljene u istraživanju Zhanga i Lucka (2008). Ukratko, nalazi istraživanja snažno govore u prilog modelima resursa, a protiv tradicionalnih modela kapaciteta radnog pamćenja.

\section{Građevni blokovi reprezentacija u VRP-u}

Neovisno o tome pristupimo li VRP-u iz perspektive modela utora ili modela resursa, važno pitanje na koje moramo odgovoriti jest na kojoj razini integracije elemenata u cjelovitu reprezentaciju postoje pretpostavljeni utori odnosno resursi. Drugim riječima, postoje li utori i resursi na razini elementarnih svojstava (npr. boje i oblici) od kojih je naš vidni svijet sastavljen ili te utore odnosno resurse raspoređujemo na već integrirane prikaze? Svaka operacionalizacija nekog spremnika pamćenja mora biti praćena mjernom jedinicom toga kapaciteta. Polazeći od modela utora, Millerov (1956) magični broj 7 ili Cowanov broj 4 (2001, 2005) nužno mora biti vezan uz operacionalizaciju jedinice koja se pamti. Ako je vidni podražaj šareni čamac, može li osoba uz njega zapamtiti još 3 ili 6 drugačijih čamaca? Ili pamćenjem samih svojstava koji čine vidnu reprezentaciju čamca popunjavamo kapacitete VRP-a? Terminologijom modela resursa isto pitanje možemo postaviti na nešto drugačiji način. Raspolažemo li odvojenim količinama resursa za pamćenje različitih svojstava ili pak raspoložive resurse dodjeljujemo integriranim objektima, bez obzira na broj svojstava od kojih su sastavljeni? Istu raspravu možemo sagledati iz druge perspektive i pokušati odgonetnuti kako se odvija povezivanje vidnih svojstava u elemente prikazane u VRP-u? Ako su temeljne jedinice analize VRP-a objekti formirani od nekoliko različitih svojstava, tada je proces povezivanja tih svojstava u objekte automatski. S druge strane, ako su temeljne jedinice analize VRP-a pojedinačna svojstva, tada preostaje otkriti princip po kojem se ta svojstva povezuju u koherentne vidne reprezentacije.

\section{Objekti kao građevne jedinice VRP-a}

Tradicionalno prihvaćeno stajalište istraživača jest kako su objekti, a ne pojedinačna svojstva od kojih su ti vidni objekti sastavljeni, temeljne jedinice analize u VRP-u. Luck i Vogel (1997) započeli su empirijsku provjeru ovih pretpostavki. U jednom od eksperimenata u provedenom istraživanju sudionicima su prikazivali nizove od 2, 4 i 6 objekata pri čemu je svaki objekt bio kombinacija četiriju svojstava 
(boja, veličina, orijentacija, oblik). Rezultati su pokazali da se, neovisno o duljini niza koji su sudionici pamtili, pamćenje pojedinih elemenata i integriranih objekata nije razlikovalo. Ipak, nakon niza od četiri zapamćena objekta odnosno svojstva (4 objekta $=16$ svojstava), uradak se u zadatku u prosjeku pogoršao, $\mathrm{i}$ to podjednako za dosjećanje pojedinih svojstava kao i cijelih objekata. Kada bi pojedina svojstva bila jedinice $\mathrm{u}$ terminima kojih VRP funkcionira, tada bi pamćenje više takvih svojstava trebalo predstavljati kognitivni trošak. Kako to nije bio slučaj u provedenom istraživanju, autori su zaključili da su integrirani objekti, bez obzira na količinu svojstava od kojih su sazdani, temeljni elementi VRP-a. Kasniji pokušaji replikacije ovih nalaza dodatno su učvrstili pretpostavku o objektima kao jedinicama pohrane u VRP-u (Delvenne i Bruyer, 2004; Vogel i sur., 2001; Walker i Miles, 1999), no ne bez iznimaka.

\section{Svojstva kao građevne jedinice VRP-a}

Istraživanja nakon Lucka i Vogela (1997) provjeravala su uvjete u kojima je moguće replicirati nalaz o neograničenom kapacitetu za pamćenje svojstava povezanih u objekte. Davis i Holmes (2005), Delvenne i Bruyer (2004, 2006), Xu (2002), te Xu i Chun (2006) pronašli su kako pamćenje pojedinih svojstava unutar objekta predstavlja trošak kada se ta svojstva nalaze na različitim dijelovima objekata. Na primjer, kada se svojstvo boje i orijentacije od kojih je objekt sastavljen ne preklapaju, sudionici lakše pamte svako od dva svojstva zasebno u odnosu na integrirani objekt (Brady, Konkle i Alvarez, 2011; Xu, 2002). Osim toga, istraživanja su pokazala i kako je pamćenje integriranih svojstava otežano kada ona dolaze iz iste kategorije (Delvenne i Bruyer, 2004; Olson i Jiang, 2002; Wheeler i Treisman, 2002).

Fougnie, Asplund i Marois (2010) u svom su istraživanju provjeravali kakav je utjecaj količine zapamćenih svojstava na preciznost dosjećanja vidnih podražaja. Kroz četiri eksperimenta sudionicima su zadavali nizove od 3 i 6 trokuta različitih orijentacija i boja, a od sudionika su tražili da na kontinuiranoj skali reproduciraju orijentaciju, boju ili i orijentaciju i boju prikazanih objekata (trokuta). Rezultati su pokazali kako se preciznost s kojom su sudionici uspjeli reproducirati oba svojstva značajno smanjujue u odnosu na pamćenje pojedinog svojstva kod pamćenja dužeg niza. Ovi rezultati govore u prilog tome kako povećavanje informacija (svojstava) koje je potrebno zapamtiti o objektu predstavlja kognitivni trošak.

Marshall i Bays (2013) pronašli su kako samo usmjeravanje pažnje na objekt s ciljem pamćenja jedne karakteristike (npr. boje) dovodi do automatskog upamćivanja irelevantnih karakteristika podražaja (npr. orijentacije). Iako upućuju na takav zaključak, ti rezultati ipak ne govore kako su sva svojstva zapamćena kao jedinstvena reprezentacija. Bays, Wu i Husain (2011) također su paradigmom kontinuirane reprodukcije provjeravali suprotstavljene pretpostavke o svojstvima i objektima kao jedinicama analize u VRP-u. Sudionicima su zadavali prikaze linija različitih boja i orijentacija i bilježili točnost reprodukcije svakog od dvaju navedenih svojstava. Kako bi odgovorili na istraživačko pitanje, usmjerili su se na povezanost 
pogrešnih reprodukcija zapamćenih svojstava. Pretpostavili su kako će se, ako su objekti jedinice analize VRP-a, pogreške u reprodukciji svojstava u potpunosti preklapati. Ako su pak pojedinačna svojstva jedinice analize, tada sudionici mogu zapamtiti orijentaciju linije, ali ne i njezinu boju (i obrnuto) što će rezultirati nultom korelacijom $\mathrm{u}$ pogreškama reprodukcije. Autori su $\mathrm{u}$ istraživanju pronašli nezavisnost pogrešaka reprodukcije dvaju svojstava, dodatno potvrđujući pretpostavku o svojstvima objekata kao građevnim jedinicama reprezentacije objekata u VRP-u.

\section{Integrirani pristup kodiranju svojstava i objekata}

Iako novija istraživanja govore u prilog pretpostavci o svojstvima kao građevnim jedinicama VRP-a, moguće je da se kodiranje informacija odvija na više od jedne razine. U spomenutom su istraživanju Fougnie i suradnici (2010) jednim od provedenih eksperimenata pokazali kako je pamćenje većeg broja svojstava unutar manjeg broja objekata lakše nego pamćenje jednakog broja svojstava koja nisu povezana u objekte. Do istih su nalaza došli i Olson i Jiang (2002), koji su pokazali kako je pamćenje dvaju objekata sastavljenih od različitih boja i orijentacija (četiri elementa) lakše nego pamćenje boje dvaju objekta i orijentacije drugih dvaju objekata (također četiri elementa).

Kako bi obuhvatili nalaze istraživanja koja govore u prilog jednoj ili drugoj pretpostavci o tome što su primarne jedinice analize VRP-a, Brady i suradnici (2011) pretpostavili su postojanje hijerarhijskog sustava kodiranja. Njihov predloženi model pretpostavlja dvije razine na kojima se odvija kodiranje informacija: 1) na višoj razini modela dolazi do reprezentacije integriranih objekata; 2) na nižoj razini odvija se reprezentacija pojedinačnih svojstava objekata. Svaki objekt tako predstavlja skup informacija distribuiranih preko dvije razine kodiranja. Informacije na nižoj razini kodiranja nisu u potpunosti zavisne te je moguće da se neka svojstva već na toj nižoj razini kodiraju slabije, ali i da se u potpunosti zaborave. Isti model pretpostavlja da kodiranje novog skupa informacija kako bi se zapamtilo samo jedno svojstvo (npr. boja) može predstavljati kognitivni trošak. Točnije, autori pretpostavljaju da je lakše u postojeći skup informacija o objektu dodati još jedno svojstvo, nego pamtiti pojedinačno svojstvo kao zasebni objekt. Ako VRP doista funkcionira tako, tada bi ovakav hijerarhijski model mogao obuhvatiti većinu nesukladnih nalaza o kodiranju objekata i svojstava. Iako neka istraživanja idu u prilog upravo ovakvom konceptu VRP-a (Fougnie i sur., 2010; Hollingworth i Rasmussen, 2010; Wheeler i Treisman, 2002; Wood, 2009) za sada nije provedeno istraživanje koje bi direktno provjeravalo sve pretpostavke ovog modela. 


\section{Stvaranje reprezentacija}

Svaki bi model RP-a trebao imati jasne hipoteze i o procesima poput kodiranja, dosjećanja i zaboravljanja. Dok su faze dosjećanja i zaboravljanja relativno istražene, istraživanja početne faze, kodiranja ili konsolidacije informacija u VRP-u nude donekle oprečne nalaze (Nieuwenstein i Wyble, 2014; Suchow, Fougnie, Brady i Alvarez, 2014). Konsolidacija predstavlja proces transformacije perceptivnih u trajnije reprezentacije otporne na nove ulazne perceptivne informacije (Jolicoeur i Dell'Acqua, 1998; Vogel, Woodman i Luck, 2006). Tradicionalni modeli VRP-a, poput Cowanova (2001), pretpostavljaju jednostavne procese kodiranja i u većoj su mjeri usmjereni na procese zadržavanja informacija. Cowan (2005) tako pretpostavlja da, između niza vidnih podražaja, osoba po slučaju odabire i kodira samo dio njih, dok o preostalima ne pohranjuje nikakve informacije. Brady i Alvarez (2011) te Brady i Tenenbaum (2013) pokazali su pak kako je odabir informacija koje ćemo kodirati snažno određen konfiguracijom vidnih podražaja. Dio odgovora o prirodi stvaranja reprezentacija opisan je već u dijelu ovoga rada koji opisuje građevne jedinice VRP-a. Stoga ćemo se ovdje osvrnuti samo na komponentu kodiranja koja je tijekom vremena privukla značajniju pozornost istraživača vrijeme potrebno za kodiranje informacija u VRP-u.

\section{Vrijeme kodiranja - treptaj pažnje i vidno maskiranje}

Dva su široka istraživačka pravca obilježila područje istraživanja vremena konsolidacije sadržaja u VRP-u. Prvi se pristup temelji na nalazu kako prilikom brzih uzastopnih prikaza dvaju vidnih podražaja sudionici lošije pamte ili čak ne uspijevaju zamijetiti drugi prikazani vidni podražaj, kada je on prikazan u periodu kraćem od 500ms nakon prvog (Broadbent i Broadbent, 1987; Shapiro, Raymond i Arnell, 1994; Wyble, Bowman i Nieuwenstein, 2009). Ovaj se fenomen naziva treptaj pažnje, a odnosi se na neuspjeh kodiranja vidnih sadržaja zbog vremenske blizine s nekom drugom, tek viđenom informacijom koja se kodira. Iako tretiran kao fenomen iz područja vidne percepcije i VRP-a, većina je provedenih istraživanja upotrebljavala slova ili brojke kao podražajni materijal, a tek je manji broj istraživanja upotrebljavao iskuljučivo vidne podražaje (Ross i Jolicoeur, 1999). Teorije treptaja pažnje slažu se kako je ovaj fenomen posljedica nedostupnosti VRPa zbog konsolidiranja kronološki prvoga prikazanoga vidnog podražaja, što sugerira da VRP ima ograničene kapacitete raspoložive za kodiranje (Dux i Marois, 2009; Martens i Wyble, 2010). Iako to nijedno istraživanje nije eksplicitno tvrdilo (Vogel i sur., 2006), period od $500 \mathrm{~ms}$ nakon prezentacije prvoga vidnog podražaja u kojem je moguće opaziti treptaj pažnje, često se navodi kao vrijeme potrebno za konsolidaciju toga prvog podražaja.

Drugi značajni pristup polazi od istraživanja provedenih pomoću paradigme vidnog maskiranja gdje se vrijeme konsolidacije procjenjuje pomoću stupnja u kojem vidno maskiranje narušava pamćenje prethodno prikazanoga vidnog 
podražaja (Bays i sur., 2011; Gegenfurtner i Sperling, 1993; Ogmen, Breitmeyer i Melvin, 2003; Vogel i sur., 2006; Woodman i Vogel, 2005). U pozadini ovakvog pristupa mjerenja trajanja konsolidacije stoji pretpostavka kako se konsolidacija može nastaviti samo dok je reprezentacija vidnog podražaja dostupna u senzornom sustavu (Breitmeyer i Ogmen, 2000). Kako svaki maskirajući podražaj zauzima mjesto prethodnoga vidnog podražaja u senzornom sustavu, pretpostavlja se kako maskirajući podražaji unutar određenoga vremenskog intervala prekidaju ili ometaju konsolidaciju u VRP-u. Iz toga proizlazi da je svaki vidni podražaj kojeg se nakon maskiranja sudionici mogu dosjetiti bio kodiran prije prikazivanja maskirajućeg podražaja. Vogel i suradnici (2006) su paradigmom maskirajućih podražaja, koristeći jednostavne vidne podražaje (boje), pronašli kako je za kodiranje jednoga objekta $u$ VRP-u potrebno oko $50 \mathrm{~ms}$. U tom je istraživanju s porastom dužine niza koji se pamtio rastao i interval (50ms za svaki element) nakon prezentacije niza u kojem je maskirajući podražaj interferirao s konsolidacijom elemenata niza.

Dva opisana pristupa istražuju vrijeme konsolidacije bitno drugačijim paradigmama. Dok pristup koji se oslanja na fenomen treptaja pažnje analizira koliko je trajanje proaktivne interferencije za sukcesivne vidne sadržaje, paradigma vidnoga maskiranja analizira vrijeme retroaktivne interferencije maskirajućeg podražaja za prethodne vidne sadržaje. Isto tako, na temelju istraživanja s ove dvije paradigme (500ms nasuprot 50ms) vremena procjene konsolidacije bitno se razlikuju. Nadalje, dva pristupa imaju i suštinske razlike u pretpostavkama - polazeći iz paradigme fenomena treptaja pažnje, sudionici bi trebali biti "slijepi" za maskirajući podražaj; jednako, polazeći iz paradigme vidnog maskiranja, konsolidacija bi trebala biti narušena sukcesivnim podražajima na koje su sudionici, $u$ istraživanjima treptaja pažnje, "slijepi". Nieuwenstein i Wyble (2014) su sudionicima prezentirali vidne podražaje za pamćenje, a zatim i maskirajuće podražaje. Nakon prezentacije maskirajućeg podražaja sudionici su rješavali zadatak vidne diskriminacije. Prema hipotezi temeljenoj na fenomenu pažnje, zadatak vidne diskriminacije trebao bi dodatno narušiti proces konsolidacije. Rezultati su pokazali kako zadatak vidne diskriminacije dovodi do retroaktivne interferencije povrh vidnog maskiranja, što pokazuje kako konsolidacija sadržaja u VRP-u traje i nakon jednostavnog maskiranja. Sami interferirajući efekt padao je gotovo linearno u periodu od 250 do $1000 \mathrm{~ms}$ nakon prezentacije vidnog podražaja koji su sudionici trebali upamtiti, što pokazuje kako je sam proces konsolidacije duži no što se to prethodno pretpostavljalo.

\section{Pogreške u dosjećanju}

Pažnja istraživača VRP-a većinu je povijesti istraživanja ovog koncepta bila usmjerena na procjenu najveće moguće količine informacija koju osoba može upamtiti (Brady i sur., 2011). Tek su se pojavom modela resursa i bitno različitim hipotezama o prirodi VRP-a intenzivirali istraživački napori vezani uz druge karakteristike VRP-a, poput pogrešaka u dosjećanju. Stoga ne čudi da je većina 
hipoteza o pogreškama dosjećanja proizašla iz modela resursa. U ovom dijelu osvrnut ćemo se na tri najčešće istraživana izvora pogrešaka u dosjećanju.

\section{Varijabilna preciznost pamćenja}

Prvi izvor pogrešaka u dosjećanju sadržaja VRP-a ujedno odražava i važnu teorijsku pretpostavku koja razlikuje tradicionalne modele VRP-a od onih novijih. To je pretpostavka o varijabilnom pamćenju objekata unutar ukupnog sadržaja VRPa, odnosno šumu u procesu kodiranja. Sama ideja ipak nije toliko nova kao njezin teorijski doprinos u području VRP-a (Navon, 1984; Navon i Gopher, 1979; Norman i Bobrow, 1976). Središnja pretpostavka o varijabilnom kodiranju jest ta da se reprezentacije u VRP-u natječu za ograničenu količinu kognitivnih resursa, a preciznost svake od reprezentacija upamćenog materijala ovisit će o količini resursa koja je posvećena svakom upamćenom objektu. Takvo kodiranje dovest će stoga do pogrešaka koje će se razlikovati od objekta do objekta. Izvori variranja u kodiranju, a samim time i pogrešaka dosjećanja mogu biti i internalni, ali i eksternalni. Ma i suradnici (2014) navode neke od tih uzroka, poput razlika i sličnosti između podražaja koji se pamte (Girshick, Landy i Simoncelli, 2011), kontekstualnih utjecaja setova objekata koji se pamte (Brady i Tenenbaum, 2013), fluktuacija u pažnji (Lara i Wallis, 2012) te šuma nastalog u fazi zadržavanja informacija (Fougnie i sur., 2012; Shafi i sur., 2007).

Modeli kodiranja s varijabilnom preciznosti pretpostavljaju kako je preciznost upamćenog varijabilna čak i kada je količina informacija koju je potrebno upamtiti konstantna, kao i onda kada upamćeni sadržaji ne prelaze količinu informacija koju tradicionalni modeli predlažu kao gornju granicu kapaciteta VRP-a (Fougnie i sur., 2012; van den Berg i sur., 2012). Dok tradicionalni modeli pretpostavljaju da je objekt upamćen ili savršeno precizno ili uopće nije upamćen (Luck i Vogel, 1997), noviji modeli pretpostavljaju kako je, unutar distribucije velikog broja odgovora, preciznost svakoga upamćenog objekta moguće opisati distribucijom vjerojatnosti. U terminima ranije opisanih modela mješovitih distribucija varijabilna preciznost upamćenog pretpostavlja kako se odgovori $u$ istraživanju ne mogu opisati jednom normalnom distribucijom s fiksnom preciznosti, već kombinacijom velikog broja normalnih distribucija koje odražavaju različite preciznosti. Provedena istraživanja koja su testirala ovu pretpostavku pronašla su kako model mješovitih distribucija s kombinacijom velikog broja normalnih distribucija bolje pristaje podacima od modela koji sadrži samo komponentu zapamćenih objekata i komponentu pogađanja (Bae, Olkkonen, Allred, Wilson i Flombaum, 2014; Fougnie i sur., 2012; van den Berg i sur., 2012, 2014). Važno se osvrnuti na ove nalaze i u kontekstu često pretpostavljanog odnosa kvalitete i kvantitete pamćenja. Velik broj modela VRP-a pretpostavlja, barem implicitno, deterministički odnos količine i preciznosti upamćenog materijala (Suchow i sur., 2014). Istraživanja koja potvrđuju pretpostavku o varijabilnoj preciznosti pamćenja (čak i kod nizova konstantne 
duljine) govore kako taj odnos ne može biti jednostavno opisan linearnom funkcijom.

\section{Pogreške povezivanja svojstava}

Jedan od mogućih izvora pogrešaka $u$ dosjećanju jest i netočno povezivanje svojstava $u$ jedinstveni objekt ili reprezentaciju. U istraživanjima VRP-a nizovi podražaja često su objekti sastavljeni od dva ili više svojstva (npr. geometrijski lik i boja). U fazi dosjećanja od sudionika se traži da na temelju jednog svojstva (geometrijskog lika) reproduciraju drugo svojstvo (boju). U tim situacijama sudionici mogu točno zapamtiti sva pojedinačna svojstva, ali ih pritom pogrešno povezati $u$ objekte. Jednako tako, u istraživanjima u kojima se ispituje pamćenje samo jednog svojstva (npr. boje) sudionicima se u fazi dosjećanja na temelju prostornog položaja objekta u upamćenom nizu indicira koji dio niza trebaju reproducirati. Samim time, osim informacija o svojstvu (boji) sudionici moraju upamtiti njihov prostorni razmještaj. Jednako kao i u prošlom primjeru, sudionici mogu upamtiti sve boje, ali ne i njihov točan razmještaj (Bays i sur., 2009).

Jedan od načina na koji se analitičkim postupkom može detektirati proporcija odgovora nastala zbog pogrešne reprodukcije svojstva jest dodavanje nove komponente u modelu mješovitih distribucija - komponenta odgovora centriranih oko podražaja koji su bili prikazani, ali čije se dosjećanje nije tražilo. Takav model mješovitih distribucija ima tri komponente rezultata - dio koji odražava upamćene podražaje, dio koji odražava pogreške povezivanja svojstava i dio koji odražava slučajno pogađanje. Bays i suradnici (2009) u svom su istraživanju testiranjem trokomponentnog modela pronašli kako značajna proporcija odgovora proizlazi iz pogrešnog povezivanja svojstva boje i njihove lokacije tijekom prikaza. Ta proporcija odgovora rasla je s porastom broja boja koje su sudionici trebali upamtiti te se njome moglo obuhvatiti gotovo $30 \%$ odgovora kod nizova sastavljenih od šest elemenata. I druga su istraživanja pronašla kako je moguće znatnu proporciju odgovora pripisati upravo toj komponenti (Bays i sur., 2011; Emrich i Ferber, 2012; Fougnie i sur., 2010) te da proporcija takvih odgovora raste s povećanjem kognitivnog opterećenja (Bays i sur., 2011; Gorgoraptis i sur., 2011). Van den Berg i suradnici (2014) su u svom pregledu pronašli kako model koji uključuje treću komponentu odgovora bolje pristaje podacima od modela koji ga ne uključuje te da sa svakom dodatnom česticom koju sudionici trebaju upamtiti proporcija odgovora nastalih zbog pogrešnog povezivanja svojstava raste za oko $2 \%$.

\section{Pogreške zbog pogađanja}

Za kraj ovog dijela osvrnimo se još na pogreške nastale zbog pogađanja, dio odgovora sudionika koji je velikim dijelom objašnjen dvama prethodnim izvorima pogrešaka. Naime, većina analiza modela mješovitih distribucija rezultate dijeli u komponentu zapamćenih odgovora i odgovora nastalih zbog slučajnog pogađanja. 
Neki modeli, poput onog van den Berga i suradnika (2012) pretpostavljaju kako opažena uniformna komponenta u rezultatima sudionika zapravo ne odražava slučajno pogađanje, već elemente zapamćene vrlo niskom preciznošću. Zbog niske preciznosti pamćenja njihova je varijanca vrlo velika i s gotovo neznatnim grupiranjem rezultata oko neke vrijednosti, čime nalikuju na uniformnu distribuciju koju su neki autori pripisali slučajnom pogađanju (Zhang i Luck, 2008). U već spomenutim istraživanjima van den Berga i suradnika $(2012,2014)$ model koji je pretpostavljao da podaci odražavaju odgovore koji su rezultat pamćenja i slučajnog pogađanja, lošije je pristajao podacima u odnosu na model koji je pretpostavljao da je naizgled uniformni dio distribucije rezultat uprosječivanja većeg broja odgovora niske preciznosti. U istraživanju Schneegansa i Baysa (2016) usporedba modela s različitim brojem komponenata pokazala je kako model koji pretpostavlja postojanje odgovora vezanih uz traženi element te odgovora nastalih zbog pogrešnog povezivanja bolje pristaje podacima od modela koji pretpostavlja postojanje odgovora vezanih uz traženi element te slučajno pogađanje. Iako je neupitno da sudionici ponekad pogađaju čak i kod vrlo kratkih nizova koji se pamte, čini se kako je proporcija pogreške nastala zbog slučajnog pogađanja mnogo manja no što bi se dalo naslutiti iz ranijih istraživanja.

\section{Zaboravljanje}

Povijesno gledano, dvije su suprotstavljene hipoteze definirale područje istraživanja prirode zaboravljanja informacija iz RP-a: hipoteza o osipanju informacija i hipoteza o interferenciji. Prema prvoj hipotezi informacije iz RP-a nestaju osipanjem odnosno samim protokom vremena (Barrouillet, Bernardin i Camos, 2004; Cowan, Saults i Nugent, 1997). Alternativno objašnjenje nudi hipoteza o interferenciji pretpostavljajući kako do zaboravljanja dolazi ulaskom novih informacija u ograničeni spremnik radnog pamćenja (Oberauer, Lewandowsky, Farrell, Jarrold i Greaves, 2012). Osim u uzrocima zaboravljanja, ova dva pristupa zauzimaju i različite perspektive oko mehanizama koji priječe zaboravljanje informacija. Prva hipoteza pretpostavlja da se sadržaji RP-a čuvaju mehanizmom osvježavanja zapamćenog, dok druga hipoteza predlaže mehanizam izbacivanja sadržaja koji ometaju zapamćeno. Ukratko, dok jedan pristup pretpostavlja da pasivan pristup sadržajima RP-a dovodi do gubljenja tih sadržaja, drugi pristup pretpostavlja kako pasivan pristup interferirajućem materijalu, ali ne i sadržajima koje želimo zapamtiti, dovodi do gubljenja informacija koje želimo zadržati. Ono u čemu se oba pristupa slažu jest pretpostavka kako mehanizam koji štiti sadržaje od zaboravljanja zahtjeva resurse pažnje.

\section{Zaboravljanje osipanjem}

Unutar same hipoteze o osipanju sadržaja u radnom pamćenju postoje bitne razlike između modela koji zastupaju tu hipotezu. Neki istraživači pretpostavljaju 
kako sam prolazak vremena dovodi do osipanja sadržaja RP-a (Ricker i Cowan, 2010, 2014). Drugi pak tvrde kako prolazak vremena dovodi do osipanja zapamćenih informacija, ali samo kada su onemogućeni automatski procesi koji inače spontano štite zapamćene sadržaje od zaboravljanja (Barrouillet i sur., 2004). Ricker i Cowan $(2010,2014)$ testirali su hipotezu o jednostavnom osipanju upamćenog materijala. Svojim su sudionicima prezentirali vidne podražaje te od njih tražili da, nakon perioda zadržavanja tih informacija, odgovore je li prezentirani vidni podražaj bio dio prezentiranog niza. Autori su u oba istraživanja opazili da do zaboravljanja osipanjem dolazi i onda kada u periodu zadržavanja informacija sudionici nisu morali obavljati neki sekundarni zadatak. Woodman, Vogel i Luck (2012) te Morey i Bieler (2013) u svojim su istraživanjima replicirali rezultate Rickera i Cowana (2010, 2014; za suprotne nalaze vidi Vogel i sur., 2001). Koristeći ranije opisane kontinuirane skale za procjenu preciznosti upamćenih vidnih podražaja, Zhang i Luck (2008) te Pertzov i suradnici (2013) pronašli su porast u pogreškama procjena $\mathrm{s}$ porastom trajanja intervala pamćenja.

Kao što je rečeno, ne podrazumijevaju sve teorije osipanja da do zaboravljanja sadržaja dolazi samim protokom vremena. Teorija vremenski ograničenog dijeljenja resursa (engl. Time-based resource-sharing model - TBRS; Barrouillet, Portrat i Camos, 2011) navodi kako do osipanja dolazi samo kada su onemogućeni automatski procesi osvježavanja zapamćenog materijala (na primjer, kao što je to $\mathrm{u}$ situaciji obavljanja nekog sekundarnog zadatka tijekom faze retencije zapamćenog). Souza, Rerko i Oberauer (2015) testirali su pretpostavku o utjecaju osvježavanja zapamćenog sadržaja na zaboravljanje vidnog materijala. Kroz tri eksperimenta svojim su sudionicima u periodu nakon prikazivanja podražajnog materijala signalizirali lokaciju pojedinog podražaja na koji su morali pomisliti (osvježiti ga). Manipulirajući frekvenciju osvježavanja, pronašli su kako su se dijelovi niza koji su češće bili osvježavani pamtili preciznije, čime su djelomično potvrdili teoriju TBRS. Ipak, jedan od pronađenih nalaza tog istraživanja ne ide u prilog teoriji TBRS. Prema ovoj teoriji, elementi koji u retenciji ni jednom nisu bili osvježeni trebali bi biti podložni osipanju. Kada je dosjećanje tih podražaja uspoređeno s dosjećanjem nizova koje su sudionici mogli osvježavati spontano (bez signaliziranja), nije pronađena nikakva razlika u njihovu upamćivanju. Elementi koji se u jednoj eksperimentalnoj situaciji nisu stizali osvježiti pamćeni su jednako precizno kao i elementi koji su se mogli osvježavati spontano. Nepostojanje razlike između dvije eksperimentalne situacije govori kako do osipanja zapamćenog sadržaja ne dolazi uvijek kada je onemogućeno njegovo osvježavanje.

\section{Zaboravljanje interferencijom}

U istraživanjima verbalnog RP-a velik broj istraživanja govori u prilog pretpostavkama retroaktivne interferencije, a protiv pretpostavki zaboravljanja osipanjem (Berman, Jonides i Lewis, 2009; Lewandowsky, Oberauer i Brown, 2009; Oberauer i Lewandowsky, 2008; Oberauer i sur., 2012; White, 2012). U području 
istraživanja VRP-a istraživači se u većoj mjeri usmjeravaju na utjecaj proaktivne interferencije kao mehanizma zaboravljanja. Objašnjenje se temelji na pretpostavci da se reprezentacije VRP-a preklapaju i međusobno interferiraju u funkciji vremenske profiliranosti, tj. njihove izoliranosti u (psihološkom) vremenskom prostoru. Prema teorijama vremenske profiliranosti (Brown, Neath i Chater, 2007) psihološka je reprezentacija vremena komprimirana na način da se intervali između događaja smanjuju što se više udaljavamo od tih intervala. Posljedica toga je da profiliranost događaja, u odnosu na druge događaje, ovisi o relativnoj količini vremena koja je protekla od njih (Shipstead i Engle, 2013). Pretpostavke su ovog modela da se sadržaji kodirani vremenski udaljeni jedan od drugog dozivaju lakše od onih koji su kodirani vremenski blizu.

Souza i Oberauer (2015) su paradigmom kontinuirane procjene provjeravali ulogu proaktivne interferencije u VRP-u. Oni su u istraživanju kombinirali dva intervala retencije (kratki i dugi) s dva vremenska intervala između učenih nizova (kratki i dugi). Na taj su način dobili četiri kombinacije intervala i tri stupnja profiliranosti nizova (kombinacija oba kratka i kombinacija oba duga intervala rezultirala je jednakom profiliranosti). Ako na zaboravljanje u VRP-u utječe proaktivna interferencija, tada bi veća profiliranost (veći interval između učenja dva niza uz kraće vrijeme retencije) trebala dovesti do manje interferencije i preciznijeg pamćenja. Ključno, kombinacija oba kratka i kombinacija oba duga intervala trebala bi rezultirati jednakim pogreškama procjene jer je njihova profiliranost bila jednaka. Pristup osipanja ovdje bi pretpostavio samo razlike između situacija s različitim intervalima retencije. Rezultati su pokazali da su pogreške procjene bile manje što je profiliranost nizova bila veća. Navedeno govori u prilog pretpostavkama teorija profiliranosti. Naknadne su analize pokazale kako je vjerojatnost dosjećanja, ali ne i preciznost dosjećanja, varirala s profiliranosti: što je profiliranost bila veća, rasla je vjerojatnost dosjećanja. U sličnom istraživanju, koristeći eksperimentalnu paradigmu detekcije promjene, Shipstead i Engle (2013) testirali su pretpostavke teorije vremenske profiliranosti. Dobiveni su rezultati podržali hipotezu o proaktivnoj interferenciji, a ne vremenskom osipanju, kao mehanizmu zaboravljanja informacija.

\section{Zaključak}

U ovom smo preglednom radu prikazali najvažnije karakteristike VRP-a uključujući jedinice pamćenja, prirodu reprezentacija i pohrane informacija, kao i faze kodiranja, dosjećanja i zaboravljanja. Kao što je već rečeno, VRP je gotovo cijelu svoju povijest proveo u sjeni verbalne komponente radnog pamćenja. Ipak, unazad 15 godina uloženi su metodološki i statistički napori kako bi se nadoknadila empirijska i teorijska zaostajanja za područjem istraživanja verbalnoga radnog pamćenja. 
Važno je sumirati statuse nekih ideja opisanih u ovom preglednom radu. Prvo, premda su tradicionalni modeli VRP-a dominirali područjem istraživanja gotovo 40 godina, modeli resursa imaju sve snažniju empirijsku potvrdu (Ma i sur., 2014). Iako predstavlja lak prečac prilikom opisivanja VRP-a, fiksan broj zapamćenih elemenata teško je branjiv, čak i iz pozicija novijih modela utora koji su pojam utora učinili bitno fleksibilnijim kako bi mogli objasniti novije spoznaje o VRP-u. Drugo, čini se kako rasprava o jedinicama pamćenja (objekti nasuprot svojstvima) najizglednije razrješenje ima u hijerarhijskim modelima VRP-a (Brady i Alvarez, 2011; Brady i sur., 2011). Iako nedostaje empirijska potvrda modela takvog pamćenja u cijelosti, sadašnja istraživanja pokazuju kako bi hijerarhijski modeli VRP-a mogli objediniti nesukladnosti u nalazima istraživanja onih autora koji zagovaraju objekte i onih koji zagovaraju svojstva kao jedinice VRP-a. Treće, faza kodiranja informacija u VRP-u područje je istraživanja u kojem je nedorečenost istraživanja možda i najočitija. $\mathrm{Na}$ primjer, zaključci o samom vremenu potrebnom za kodiranje informacija ovise o korištenom eksperimentalnom nacrtu, no novije i obuhvatnije provjere upućuju kako je vrijeme kodiranja složeniji koncept no što se ranije smatralo (Nieuwenstein i Wyble, 2014). S druge strane, pitanja o serijalnom ili paralelnom kodiranju tek čekaju snažniju empirijsku potvrdu. Naposljetku, područje istraživanja pogrešaka dosjećanja sadržaja iz VRP-a doživjelo je procvat pojavom novijih teorija VRP-a i analizama pogrešaka preciznosti pamćenja. Analitičke prednosti sadržane u modelima mješovitih distribucija uvelike olakšavaju analiziranje različitih izvora pogrešaka dosjećanja. Na taj način istraživanja VRP-a ne istražuju samo kako i koliko pamtimo, već i što i zašto ne uspijevamo upamtiti. Konačno, faza zaboravljanja sadržaja iz VRP-a jedno je od najuzbudljivijih područja istraživanja VRP-a. Znanstvena debata između modela osipanja i modela interferencija unazad deset godina u područje je unijela najviše metodoloških inovacija u istraživanja VRP-a. Iako istraživanja u području VRP-a donekle favoriziraju modele osipanja, prva provedena istraživanja VRP-a govore u prilog modelima interferencije.

\section{Literatura}

Atkinson, R.C. i Shiffrin, R.M. (1968). Human memory: A proposed system and its control processes. Psychology of Learning and Motivation, 2, 89-195.

Baddeley, A.D. (2007). Working memory, thought, and action. New York: Oxford University Press.

Bae, G.Y., Olkkonen, M., Allred, S.R., Wilson, C. i Flombaum, J.I. (2014). Stimulus-specific variability in color working memory with delayed estimation. Journal of Vision, 14(4), 7-7.

Barrouillet, P., Bernardin, S. i Camos, V. (2004). Time constraints and resource sharing in adults' working memory spans. Journal of Experimental Psychology: General, 133(1), 83-100. 
Barrouillet, P., Portrat, S. i Camos, V. (2011). On the law relating processing to storage in working memory. Psychological Review, 118(2), 175-192.

Bays, P.M., Catalao, R.F.G. i Husain, M. (2009). The precision of visual working memory is set by allocation of a shared resource. Journal of Vision, 9(10), 7-7.

Bays, P.M., Gorgoraptis, N., Wee, N., Marshall, L. i Husain, M. (2011). Temporal dynamics of encoding, storage, and reallocation of visual working memory. Journal of Vision, $11(10), 6-6$.

Bays, P.M. i Husain, M. (2008). Dynamic shifts of limited working memory resources in human vision. Science, 321(5890), 851-854.

Bays, P.M., Wu, E.Y. i Husain, M. (2011). Storage and binding of object features in visual working memory. Neuropsychologia, 49(6), 1622-1631.

Berman, M.G., Jonides, J. i Lewis, R.L. (2009). In search of decay in verbal short-term memory. Journal of Experimental Psychology: Learning, Memory, and Cognition, 35(2), 317-333.

Brady, T.F. i Alvarez, G.A. (2011). Hierarchical encoding in visual working memory: Ensemble statistics bias memory for individual items. Psychological Science, 22(3), 384-392.

Brady, T.F., Konkle, T. i Alvarez, G.A. (2011). A review of visual memory capacity: Beyond individual items and toward structured representations. Journal of Vision, 11(5), 4-4.

Brady, T.F. i Tenenbaum, J.B. (2013). A probabilistic model of visual working memory: Incorporating higher order regularities into working memory capacity estimates. Psychological Review, 120(1), 85-109.

Breitmeyer, B.G. i Ogmen, H. (2000). Recent models and findings in visual backward masking: A comparison, review, and update. Perception \& Psychophysics, 62(8), 15721595.

Broadbent, D.E. i Broadbent, M.H. (1987). From detection to identification: Response to multiple targets in rapid serial visual presentation. Perception \& Psychophysics, 42(2), 105-113.

Brown, G.D.A., Neath, I. i Chater, N. (2007). A temporal ratio model of memory. Psychological Review, 114(3), 539-576.

Campana, G. (2010). Visual memory. U: B. Goldstein (Ur.), Encyclopedia of perception (str. 1093-1094). Thousand Oaks, CA: Sage Publications Inc.

Cowan, N. (2001). The magical number 4 in short-term memory: A reconsideration of mental storage capacity. The Behavioral and Brain Sciences, 24(1), 87-114.

Cowan, N. (2005). Working memory capacity. Hove, East Sussex, UK: Psychology Press.

Cowan, N., Saults, J.S. i Nugent, L.D. (1997). The role of absolute and relative amounts of time in forgetting within immediate memory: The case of tone-pitch comparisons. Psychonomic Bulletin \& Review, 4(3), 393-397.

Davis, G. i Holmes, A. (2005). The capacity of visual short-term memory is not a fixed number of objects. Memory \& Cognition, 33(2), 185-195. 
Della Sala, S., Gray, C., Baddeley, A., Allamano, N. i Wilson, L. (1999). Pattern span: A tool for unwelding visuo-spatial memory. Neuropsychologia, 37(10), 1189-1199.

Delvenne, J.F. i Bruyer, R. (2004). Does visual short-term memory store bound features? Visual Cognition, 11(1), 1-27.

Delvenne, J.F. i Bruyer, R. (2006). A configural effect in visual short-term memory for features from different parts of an object. The Quarterly Journal of Experimental Psychology, 59(9), 1567-1580.

Dux, P.E. i Marois, R. (2009). The attentional blink: A review of data and theory. Attention, Perception \& Psychophysics, 71(8), 1683-1700.

Emrich, S.M. i Ferber, S. (2012). Competition increases binding errors in visual working memory. Journal of Vision, 12(4), 12-12.

Emrich, S.M., Riggall, A.C., LaRocque, J.J. i Postle, B.R. (2013). Distributed patterns of activity in sensory cortex reflect the precision of multiple items maintained in visual short-term memory. Journal of Neuroscience, 33(15), 6516-6523.

Fallon, S.J., Zokaei, N. i Husain, M. (2016). Causes and consequences of limitations in visual working memory. Annals of the New York Academy of Sciences, 1369(1), 40-54.

Fougnie, D. (2008). The relationship between attention and working memory. U: N.B. Johansen (Ur.), New research on short-term memory (str. 1-45). NY: Nova Science Publishers.

Fougnie, D., Asplund, C.L. i Marois, R. (2010). What are the units of storage in visual working memory? Journal of Vision, 10(12), 27-27.

Fougnie, D., Suchow, J.W. i Alvarez, G.A. (2012). Variability in the quality of visual working memory. Nature Communications, 3, 1229.

Gegenfurtner, K.R. i Sperling, G. (1993). Information transfer in iconic memory experiments. Journal of Experimental Psychology: Human Perception and Performance, 19(4), 845866.

Girshick, A.R., Landy, M.S. i Simoncelli, E.P. (2011). Cardinal rules: Visual orientation perception reflects knowledge of environmental statistics. Nature Neuroscience, 14(7), 926-932.

Gorgoraptis, N., Catalao, R.F.G., Bays, P.M. i Husain, M. (2011). Dynamic updating of working memory resources for visual objects. Journal of Neuroscience, 31(23), 85028511.

Harrison, S.A. i Tong, F. (2009). Decoding reveals the contents of visual working memory in early visual areas. Nature, 458(7238), 632-635.

Hartley, A.A., Speer, N.K., Jonides, J., Reuter-Lorenz, P.A. i Smith, E.E. (2001). Is the dissociability of working memory systems for name identity, visual-object identity, and spatial location maintained in old age? Neuropsychology, 15(1), 3-17.

Hollingworth, A. i Rasmussen, I.P. (2010). Binding objects to locations: The relationship between object files and visual working memory. Journal of Experimental Psychology: Human Perception and Performance, 36(3), 543-564. 
Irwin, D.E. (1991). Information integration across saccadic eye movements. Cognitive Psychology, 23(3), 420-456.

Jiang, Y.V., Shim, W.M. i Makovski, T. (2008). Visual working memory for line orientations and face identities. Perception \& Psychophysics, 70(8), 1581-1591.

Jolicœur, P. i Dell'Acqua, R. (1998). The demonstration of short-term consolidation. Cognitive Psychology, 36(2), 138-202.

Jonides, J., Lacey, S.C. i Nee, D.E. (2005). Processes of working memory in mind and brain. Current Directions in Psychological Science, 14(1), 2-5.

Lara, A.H. i Wallis, J.D. (2012). Capacity and precision in an animal model of visual shortterm memory. Journal of Vision, 12(3), 13-13.

Lewandowsky, S., Oberauer, K. i Brown, G.D.A. (2009). No temporal decay in verbal shortterm memory. Trends in Cognitive Sciences, 13(3), 120-126.

Lewis-Peacock, J.A., Drysdale, A.T., Oberauer, K. i Postle, B.R. (2012). Neural evidence for a distinction between short-term memory and the focus of attention. Journal of Cognitive Neuroscience, 24(1), 61-79.

Luck, S.J. i Vogel, E.K. (1997). The capacity of visual working memory for features and conjunctions. Nature, 390(6657), 279-281.

Luck, S.J. i Vogel, E.K. (2013). Visual working memory capacity: From psychophysics and neurobiology to individual differences. Trends in Cognitive Sciences, 17(8), 391-400.

Ma, W.J., Husain, M. i Bays, P.M. (2014). Changing concepts of working memory. Nature Neuroscience, 17(3), 347-356.

Magnussen, S., Greenlee, M.W. i Thomas, J.P. (1996). Parallel processing in visual shortterm memory. Journal of Experimental Psychology: Human Perception and Performance, 22(1), 202-212.

Marshall, L. i Bays, P.M. (2013). Obligatory encoding of task-irrelevant features depletes working memory resources. Journal of Vision, 13(2), 21-21.

Martens, S. i Wyble, B. (2010). The attentional blink: Past, present, and future of a blind spot in perceptual awareness. Neuroscience \& Biobehavioral Reviews, 34(6), 947-957.

Mazyar, H., van den Berg, R. i Ma, W.J. (2012). Does precision decrease with set size? Journal of Vision, 12(6), 10-10.

McLachlan, G.J. i Peel, D. (2000). Finite mixture models. New York: Wiley.

Miller, G.A. (1956). The magical number seven plus or minus two: Some limits on our capacity for processing information. Psychological Review, 63(2), 81-97.

Morey, C.C. i Bieler, M. (2013). Visual short-term memory always requires general attention. Psychonomic Bulletin \& Review, 20(1), 163-170.

Navon, D. (1984). Resources - A theoretical soup stone? Psychological Review, 91(2), 216234.

Navon, D. i Gopher, D. (1979). On the economy of the human-processing system. Psychological Review, 86(3), 214-255. 
Nieuwenstein, M. i Wyble, B. (2014). Beyond a mask and against the bottleneck: Retroactive dual-task interference during working memory consolidation of a masked visual target. Journal of Experimental Psychology: General, 143(3), 1409-1427.

Norman, D.A. i Bobrow, D.J. (1976). On the analysis of performance operating characteristics. Psychochological Review, 83, 508-510.

Oberauer, K. (2002). Access to information in working memory: Exploring the focus of attention. Journal of Experimental Psychology: Learning, Memory, and Cognition, 28(3), 411-421.

Oberauer, K. i Lewandowsky, S. (2008). Forgetting in immediate serial recall: Decay, temporal distinctiveness, or interference? Psychological Review, 115(3), 544-576.

Oberauer, K., Lewandowsky, S., Farrell, S., Jarrold, C. i Greaves, M. (2012). Modeling working memory: An interference model of complex span. Psychonomic Bulletin \& Review, 19(5), 779-819.

Ogmen, H., Breitmeyer, B.G. i Melvin, R. (2003). The what and where in visual masking. Vision Research, 43(12), 1337-1350.

Olson, I.R. i Jiang, Y. (2002). Is visual short-term memory object based? Rejection of the "strong-object" hypothesis. Perception \& Psychophysics, 64(7), 1055-1067.

Palmer, J. (1990). Attentional limits on the perception and memory of visual information. Journal of Experimental Psychology: Human Perception and Performance, 16(2), 332350.

Pashler, H. (1988). Familiarity and visual change detection. Perception \& Psychophysics, 44(4), 369-378.

Pertzov, Y., Bays, P.M., Joseph, S. i Husain, M. (2013). Rapid forgetting prevented by retrospective attention cues. Journal of Experimental Psychology: Human Perception and Performance, 39(5), 1224-1231.

Phillips, W.A. (1974). On the distinction between sensory storage and short-term visual memory. Perception \& Psychophysics, 16(2), 283-290.

Postle, B.R. (2006). Working memory as an emergent property of the mind and brain. Neuroscience, 139(1), 23-38.

Postle, B.R. (2015). The cognitive neuroscience of visual short-term memory. Current Opinion in Behavioral Sciences, 1, 40-46.

Ricker, T.J. i Cowan, N. (2010). Loss of visual working memory within seconds: The combined use of refreshable and non-refreshable features. Journal of Experimental Psychology: Learning, Memory, and Cognition, 36(6), 1355-1368.

Ricker, T.J. i Cowan, N. (2014). Differences between presentation methods in working memory procedures: A matter of working memory consolidation. Journal of Experimental Psychology: Learning, Memory, and Cognition, 40(2), 417-428.

Ross, N.E. i Jolicoeur, P. (1999). Attentional blink for color. Journal of Experimental Psychology: Human Perception and Performance, 25(6), 1483-1494. 
Rouder, J.N., Morey, R.D., Cowan, N., Zwilling, C.E., Morey, C.C. i Pratte, M.S. (2008). An assessment of fixed-capacity models of visual working memory. Proceedings of the National Academy of Sciences, 105(16), 5975-5979.

Schneegans, S. i Bays, P.M. (2016). No fixed item limit in visuospatial working memory. Cortex, 83, 181-193.

Shafi, M., Zhou, Y., Quintana, J., Chow, C., Fuster, J. i Bodner, M. (2007). Variability in neuronal activity in primate cortex during working memory tasks. Neuroscience, 146(3), 1082-1108.

Shapiro, K.L., Raymond, J.E. i Arnell, K.M. (1994). Attention to visual pattern information produces the attentional blink in rapid serial visual presentation. Journal of Experimental Psychology: Human Perception and Performance, 20(2), 357-371.

Shipstead, Z. i Engle, R.W. (2013). Interference within the focus of attention: Working memory tasks reflect more than temporary maintenance. Journal of Experimental Psychology: Learning, Memory, and Cognition, 39(1), 277-289.

Souza, A.S. i Oberauer, K. (2015). Time-based forgetting in visual working memory reflects temporal distinctiveness, not decay. Psychonomic Bulletin \& Review, 22(1), 156-162.

Souza, A.S., Rerko, L. i Oberauer, K. (2015). Refreshing memory traces: Thinking of an item improves retrieval from visual working memory: Refreshing working memory traces. Annals of the New York Academy of Sciences, 1339(1), 20-31.

Suchow, J.W., Fougnie, D., Brady, T.F. i Alvarez, G.A. (2014). Terms of the debate on the format and structure of visual memory. Attention, Perception, \& Psychophysics, 76(7), 2071-2079.

Tsubomi, H., Fukuda, K., Watanabe, K. i Vogel, E.K. (2013). Neural limits to representing objects still within view. Journal of Neuroscience, 33(19), 8257-8263.

van den Berg, R., Awh, E. i Ma, W.J. (2014). Factorial comparison of working memory models. Psychological Review, 121(1), 124-149.

van den Berg, R., Shin, H., Chou, W.C., George, R. i Ma, W.J. (2012). Variability in encoding precision accounts for visual short-term memory limitations. Proceedings of the National Academy of Sciences, 109(22), 8780-8785.

Vogel, E.K., Woodman, G.F. i Luck, S.J. (2001). Storage of features, conjunctions and objects in visual working memory. Journal of Experimental Psychology: Human Perception and Performance, 27(1), 92-114.

Vogel, E.K., Woodman, G.F. i Luck, S.J. (2006). The time course of consolidation in visual working memory. Journal of Experimental Psychology: Human Perception and Performance, 32(6), 1436-1451.

Walker, P. i Miles, R. (1999). The object-based representation of partially occluded surfaces in short-term visual memory: Evidence from image combination. Memory \& Cognition, 27(3), 553-560.

Wheeler, M.E. i Treisman, A.M. (2002). Binding in short-term visual memory. Journal of Experimental Psychology: General, 131(1), 48-64. 
White, K.G. (2012). Dissociation of short-term forgetting from the passage of time. Journal of Experimental Psychology: Learning, Memory, and Cognition, 38(1), 255-259.

Wilken, P. i Ma, W.J. (2004). A detection theory account of change detection. Journal of Vision, 4(12), 11-11.

Wood, J.N. (2009). Distinct visual working memory systems for view-dependent and viewinvariant representation. PLoS ONE, 4(8), e6601.

Woodman, G.F. i Vogel, E.K. (2005). Fractionating working memory. Psychological Science, 16(2), 106-113.

Woodman, G.F., Vogel, E.K. i Luck, S.J. (2012). Flexibility in visual working memory: Accurate change detection in the face of irrelevant variations in position. Visual Cognition, 20(1), 1-28.

Wyble, B., Bowman, H. i Nieuwenstein, M. (2009). The attentional blink provides episodic distinctiveness: Sparing at a cost. Journal of Experimental Psychology: Human Perception and Performance, 35(3), 787-807.

$\mathrm{Xu}, \mathrm{Y}$. (2002). Limitations of object-based feature encoding in visual short-term memory. Journal of Experimental Psychology: Human Perception and Performance, 28(2), 458468.

Xu, Y. i Chun, M.M. (2006). Dissociable neural mechanisms supporting visual short-term memory for objects. Nature, 440(7080), 91-95.

Zhang, W. i Luck, S.J. (2008). Discrete fixed-resolution representations in visual working memory. Nature, 453(7192), 233-235.

Zokaei, N., Manohar, S., Husain, M. i Feredoes, E. (2014). Causal evidence for a privileged working memory state in early visual cortex. Journal of Neuroscience, 34(1), 158-162.

\title{
Visual Working Memory
}

\begin{abstract}
Visual working memory (VWM) is an umbrella term for processes of short-term retention and manipulation of visual information which support performance in an ongoing task. In the last decade studies in the field resulted in numerous revolutionary, both behavioural and neuropsychological, findings that have changed our understanding of VWM. In this review, we discuss some of the most important theoretical ideas and findings that have defined research orientations in the field. We begin this paper with placing VWM in the context of similar cognitive processes. After describing the most commonly used tasks in the studies of VWM, in the body of this paper we are reviewing two dominant theories of VWM - slot models and resource models of VWM. After almost forty years of empirical support of slot models, recent studies conducted under resource models paradigm are reappraising our knowledge about VWM. In order to conclude the section on VWM architecture, we review studies that aimed to answer the question whether the VWM representations are comprised of specific visual features or already integrated objects. Since the two opposing approaches cannot completely
\end{abstract}


explain existing findings, the most promising approach is the one which suggests a hierarchical model of encoding, both at the level of features and integrated objects. In the second part of the paper, we review three main tasks of VWM: encoding, retrieval, and forgetting of the information. Fields of studying these components are marked with verification of clearly opposing models, along with methodological innovations proposed in order to thoroughly examine those models. Here, we review them with an aim to elucidate the nature of core VWM components.

Keywords: visual working memory, resource models, slot models, encoding, retention, retrieval

\section{Memoria de trabajo visual}

\section{Resumen}

Memoria de trabajo visual (MTV) es el denominador común para todos los procesos de retención a corto plazo de informaciones visuales con el objetivo de realizar al instante una tarea. En los últimos diez años las investigaciones en este campo han dado como resultado muchos hallazgos revolucionarios, sea conductuales o neurológicos, que han cambiado significativamente los modos en los que hoy consideramos MTV. Esta revisión abarca algunas de las ideas teóricas y los hallazgos más importantes, que han definido direcciones de investigación dentro del campo. Empezamos el trabajo situando en breve MTV, mientras que la parte central está dedicada a presentar dos teorías dominantes de MTV y compararlas - el modelo de la muesca y el modelo de recursos. Después de casi cuarenta años de apoyar empíricamente los modelos de muesca, numerosas investigaciones, unidas en los modelos de recursos, hacen una revisión de nuestros conocimientos sobre MTV. Para concluir la cuestión de arquitectura de las representaciones de MTV, se ofrece la presentación de las investigaciones que han intentado responder a la pregunta si las representaciones de MTV constan de características visuales individuales u objetos ya integrados. Como ninguno de los enfoques no puede explicar completamente los resultados de las investigaciones, la respuesta más probable en cuanto a las unidades de codificación está en los modelos jerárquicos que presuponen que codificamos las informaciones visuales tanto en el nivel de características, como en el nivel de objetos integrados. En la segunda parte del trabajo se han descrito tres componentes importantes del funcionamiento de MTV: adoptar, recordar y olvidar informaciones. Los campos de investigación de estos componentes están marcados por las pruebas de modelos relativamente confrontados y por las novedades metodológicas introducidas con el fin de examinar las hipótesis existentes cuanto más exhaustivo.

Palabras clave: memoria de trabajo visual, modelos de recursos, modelos de muesca, memorización, retención, olvido.

Primljeno: 27.11.2016. 